\title{
The Search for Future US-China Energy Cooperation: The Case of Apple-Sun Power Joint Solar Projects
}

\author{
Anna Paskaleva \\ International Relations MA, Zhejiang University, Hangzhou, China \\ Email: anna.paskaleva@yahoo.com
}

How to cite this paper: Paskaleva, A. (2018) The Search for Future US-China Energy Cooperation: The Case of Apple-Sun Power Joint Solar Projects. Open Access Library Journal, 5: e4286.

https://doi.org/10.4236/oalib.1104286

Received: December 25, 2017

Accepted: March 26, 2018

Published: March 29, 2018

Copyright (c) 2018 by author and Open Access Library Inc.

This work is licensed under the Creative Commons Attribution International License (CC BY 4.0).

http://creativecommons.org/licenses/by/4.0/

\section{(c) () Open Access}

\begin{abstract}
The current work is a case study of three solar energy projects built with the joint efforts of Apple and Sun Power. Because of their positive results and unique characteristics, I take these projects as an example of a successful collaboration in the solar energy sector between an American and a Chinese-operating company. In the midst of complicated trade frictions between China and the US in the solar energy sector, these projects stand out in a unique way: they bring benefits to all participants, do not exacerbate the trade disputes, they are environmentally-friendly and promote peace in the Sino-American relations. The Apple-Sun Power projects also show a new approach to the overseas business model. They represent a more conscientious way of conducting business abroad since the company which is outsourcing its manufacturing (in this case Apple) uses clean energy to power its operations. Therefore, there is no exploitation of local resources, no damage to the local environment and the local people's health. On the contrary: there is an inflow of investments in the Chinese solar industry, cheap electricity for Apple and no harmful effects on the local environment. Based on the case study I make the argument that the solar energy sector is a solid ground for creating cooperation not only between companies but also between countries. Indeed, as we see in the example of Apple and Sun Power, their joint projects bring a long list of benefits without creating frictions between any parties. Viewed from a more global perspective, these projects promote the relations between China and the US and can be used as a model for promoting cooperation between other countries and consolidate peace on the global arena. In short, solar energy proves to be a good ground for developing peaceful collaboration between countries. One of the reasons is that it creates a complex interconnection between the participants and brings them to work closely together. More importantly, the result of the collaboration not only brings benefits to
\end{abstract}


the participants themselves but also helps preserve the environment and tackle climate change-issues which all nations are concerned about. This is a key feature of the collaboration in the solar energy sector-it unites actors on the international arena under ideals which all human beings share: clean environment, sustainable economy and a better future for those who will come after us.

\section{Subject Areas}

International Relations

\section{Keywords}

Solar Energy, Solar Photovoltaic Technology (Solar PV Technology), US-China Relations, Apple-Sun Power Solar Projects, Environmental Preservation, International Cooperation, Sustainable Development

\section{Introduction}

Energy security and climate change have become two central issues on the agenda of many governments around the world. In the last few years China and the US have specifically focused their efforts on addressing these challenges and have become leaders in the so called "fight against climate change" [1].

One core strategy which these two countries have focused on as a way of solving the energy security and the climate change issues, is the promotion of renewable energy and specifically-the solar photovoltaic technology.

Because of the numerous economic and environmental benefits which the solar technology brings, in the last few years it has become a central area for investments in China and in the US. Even under the presidency of Donald Trump with his rhetoric on support for the coal industry, the investment in renewable energy in the USA has been steadily growing with solar PV energy receiving the biggest share [2].

This approach has on one hand promoted the solar energy proliferation globally but in the same time it has given rise to a number of trade issues around the world with the solar trade dispute between Washington and Beijing being one of the most serious [3]. Many scholars have expressed concerns that these solar trade frictions can potentially harm the overall peaceful relations between the world's two greatest superpowers and some even go to the extent to call it "the US-China solar wars" [4].

\subsection{Fossil Fuels V/S Solar Energy}

It is commonly accepted that a state's functioning is based on energy consumption [5]. States use energy to meet the needs of their citizens, to develop the economy, to build armies and also to make alliances. In other words, countries take energy and convert it into power and wealth [6]. For this reason it is very 
important for each government that it holds control over the energy sources. This is because energy is crucial for all social, economic, and military activities. Without having access to energy resources, the economy cannot develop, the society cannot function and the existence of the state as a whole is at risk [7]. In this sense, energy security is one of the fundamental elements providing legitimacy for the state and this makes it a primary concern for every government.

As a result, countries around the world are very much focused on acquiring an unencumbered access to energy resources. And since the Industrial Revolution, the primary energy resource in the world has been fossil fuels like oil, coal and natural gas. However, despite fossil fuels' widespread use, some of their characteristics make them less attractive as an energy source in the modern world: they are unevenly distributed around the globe, the amount of reserves varies in different regions and their quantity is limited [8]. Because of this, countries demanding larger amount of fossil fuels than they have in reserves on their territory, need to import fossil fuels from other countries.

This is namely the case of China and the US: the world's strongest economies and the two top consumers of fossil fuels. The following graph (Figure 1) shows the gap between total energy production and consumption in China and in the US between 2000 and 2010 [9].

This trend continues still in 2017 with both China and the US consuming more energy than they can produce on their own. Since the energy demand in both countries is based on fossil fuels, the energy which cannot be derived by domestic reserves, is derived from imported such. This can potentially create situation of dependence between the country of import and the country of export, with the country of import being in an unfavorable position. Therefore, in certain circumstances the lack of fossil fuels domestically can potentially become a threat for the energy security of the country dependent on their import. This can easily create tensions and potentially give rise to disputes between countries and cause a threat to their security and the stability on the international arena.

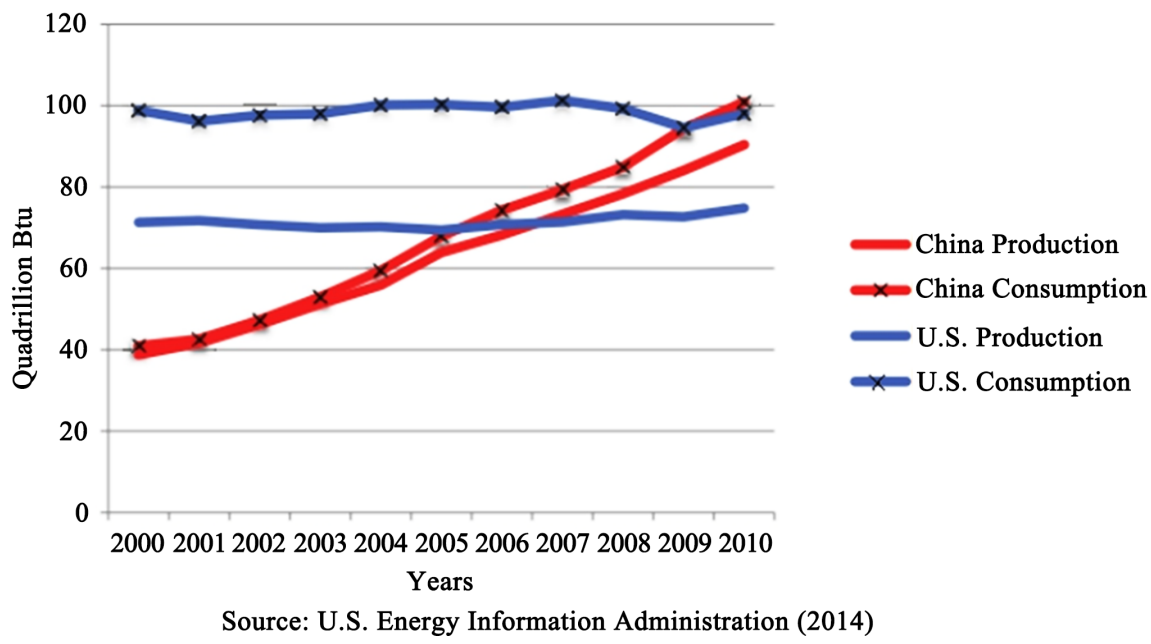

Figure 1. Total energy production and consumption. 


\section{Fossil Fuels and Global Warming}

When it comes to energy security, the countries today have also another challenge to face: environmental degradation and climate change. Burning of fossil fuels has been proven to have a direct impact on the air quality [10] and, as the scientific community has agreed, in the long run fossil fuels consumption is the main reason for exacerbating the planet's greenhouse effect and consecutively: the rise in temperatures globally [11]. This, on the other hand leads to change in climate, acidification of the oceans, extinction of many species, rise in ocean levels, change in weather patterns and other anomalies which can become a threat to all humanity [12]. At the same time, in many places around the world societies are already facing challenges which scientists believe are consequences of the large-scale burning of fossil fuels [13].

Because of this, today we find ourselves in this deadlock situation: the lack of fossil fuels means threat for the security of one country and at the same time the use of fossil fuels at such rate as today creates another type of security threat: the one caused by global warming [34]. In these complicated circumstances renewable resources like solar energy come as a promising solution. They offer answers to all the problems which the fossil fuels bring and with the right implementation could become the new leading source of energy in the world.

\section{The Advantages of Solar Energy}

In comparison to fossil fuels, renewable resources like solar energy are much more suitable for the development of the contemporary economics: they are abundant resources available all around the world, with the right technology anyone can harness their energy and they do not need to be imported and cannot be depleted no matter the rate of consumption.

Perhaps the most important advantage of the solar energy is that, unlike fossil fuels, it does not createtensions based on concerns that it can be depleted in the future. This is a very important factor in the relations between super powers like China and the US which, just like any other actor on the international arena, are constantly seeking to guarantee their own energy security [14]. In fact, some sources have recently published data that coal in China will only last for 30 more years [15]. And because fossil fuels are still the main source of energy for these two countries, the competition for energy security in its essence is a competition for guaranteeing access to fossil fuels. At the same time, this form of energy exist in limited locations around the world and can be depleted in a relatively short period of time. Therefore, these circumstances can potentially createrivalryand confrontations, harming the Sino-American relations [16].

In this context, solar energy proves to be a good alternative to fossil fuels. This is especially true in a world where energy demand is constantly growing and environmental degradation is becoming an increasingly ominous threat to the wellbeing of the whole planet. Just like all renewable resources, solar can be found with different intensity all around the globe, it cannot be depleted, it is an efficient way to generate electricity and does not create any emissions during energy generation, bringing down to minimum its impact on the environment 
[17]. This makes solar energy a good way to promote peace and bring international actors to work together. Because of this, the governments of China and the US have put renewable resources, including solar energy at the center of their agenda for future development [18].

Indeed, in the last few years, solar energy from all renewable resources is the one which has received the largest portion of investments and has been the subject of considerable technological innovation. Additionally, the solar industry is having a positive impact on the Sino-American relations by creating numerous opportunities for collaboration. Proof for that can be found in the growing number of joint ventures between Chinese and American solar companies [19], joint policies for the proliferation of solar energy crafted by the two governments [20], numerous examples for collaborations in the area of solar research and development [21] and an extensive scientific exchange of solar technology [22] [23]. All these examples, as well as the increasing importance of the solar technology around the world come to show that the solar industry per se is a suitable ground for building peaceful collaboration between actors on the international arena.

\subsection{The US-China Solar Trade Wars}

The main argument in this research is that solar energy is a suitable ground for building cooperation between international players and hence: promote peace in the international arena. Nonetheless, one should not underestimate the seriousness of the Sino-American solar trade conflicts-a persisting issue which the solar industry has given rise to. It seems to be the only challenge to announcing solar energy as the ultimate solution for promoting economic development, energy security, environmental protection and peace. Removing this obstacle is a crucial step towards making the solar industry a solid basis for cooperation and promotion of peaceful relations between China and the US.

Since entering the global solar PV market in the beginning of the 2000s, China quickly become the global hub for solar technology manufacturing and development. As a main driving force behind this phenomenon, many researchers point out the role of the Chinese government with its huge investments in the national renewable energy sector [24]. According to official data released by the National Energy Administration USD 361 billion are going to be injected in China's renewable energy industry in the span of just three years between 2017 and 2020 [25].

Similar to China, the solar photovoltaic industry (solar PV industry) in the US has undergone a considerable development [26]. Its process, however, was quite different from the one we've witnessed in China. The evolution of the solar PV technology in the US started as far back as the mid-90's and for a period of around ten years, thanks to the extensive research and development carried out by American PV companies and scientific institutes, the solar PV technology experienced a considerable improvement [27]. Later on, in the beginning of the 2000 s, American PV companies transferred this technology to China by forming 
joint ventures with local companies and US financing was another crucial factor for the development of the Chinese solar PV industry in its early stages [28].

Today, however, the situation in the solar market is completely different: while not long ago the US was considered the pioneer in the solar PV industry and one of the leaders in the manufacturing of this technology, in 2008 China stepped up the manufacturing of solar PV components and in a short period of time took over the global solar PV market. Meanwhile in the US the demand for solar PV installations has been growing steadily while the local manufacturing has dropped dramatically. Figure 2 visually represents the above mentioned phenomenon.

The graph represents the global market share (by country) for solar photovoltaic cells manufacturing-the basic component of the solar photovoltaic modules. It clearly shows a sharp decline in the manufacturing of solar cells in the US and Germany-the two country-leaders in the solar industry until 2008. This decline coincides with the start of a massive large-scale production of the same component in China.

Indeed, only in the span of 5 years the Chinese solar PV industry made a great leap forward and underwent a development unprecedented in any other part of the world or in any other industry. This phenomenon can be observed in Figure 3 which shows the cumulative capacity of solar PV installations in China between 2000 and 2016.

This is a graphic representation of the exponential growth of solar PV installations on the territory of China. It also comes to show another key driving forces behind the massive solar PV manufacturing in China: the huge local demand. Nevertheless, while in the US the market demand is met predominantly with

\section{Solar PV Module Manufacturing by Country} 1995-2015

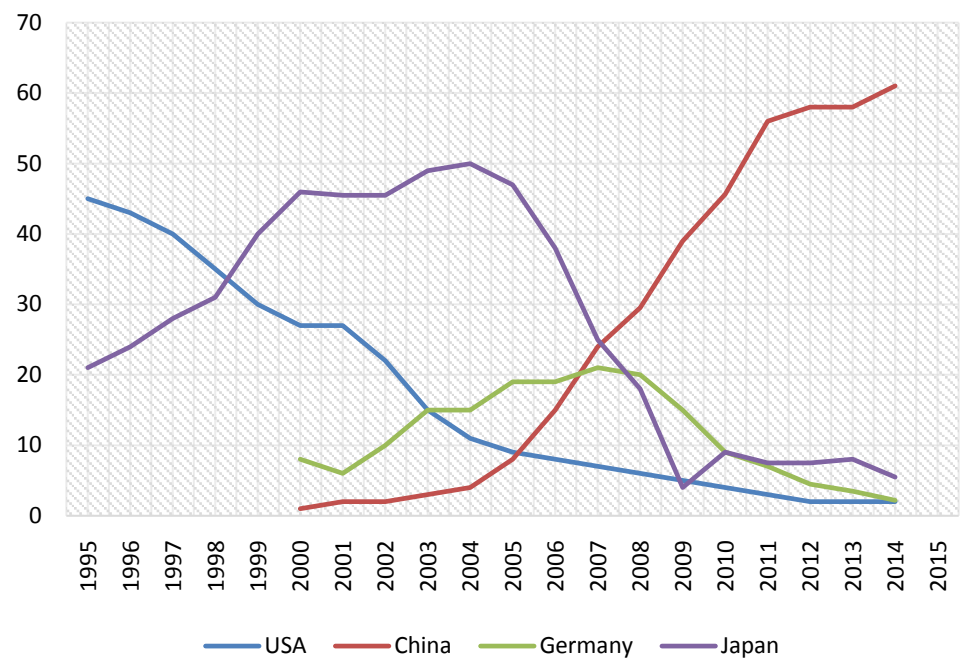

Figure 2. Recent international market share of photovoltaic cells [29]. Source: PV Magazine and The Asia-Pacific Journal, Japan Focus. 


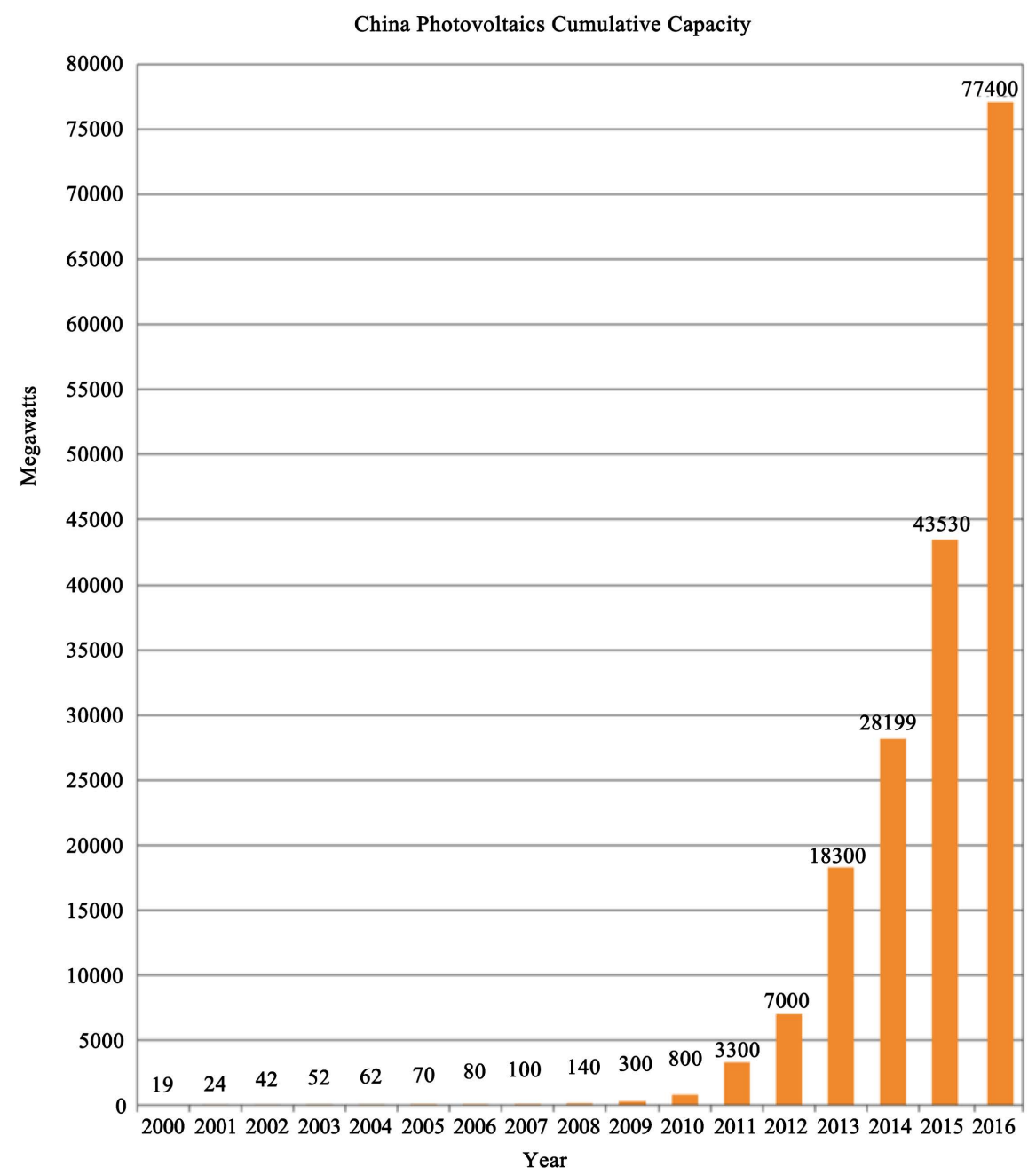

Figure 3. Photovoltaic cumulative capacity in China (2000-2016) [30].

imported PV components, in China the demand is met entirely with local production. This creates an unfair situation for the American side and represents yet another factor exacerbating the tensions between the two super powers in the solar industry.

In short, thanks to a number of factors, including the financial support of the Chinese government, the technological know-how provided by American solar companies and a local market with huge demand for solar installations, the Chinese solar manufacturers succeeded to gain the biggest share of the global solar PV market in the span of only four years (between 2008 and 2011) and have been dominating it since.

One of the key reasons for China's domination on the solar market is the low price of the solar PV products manufactured there. For this reason, when building solar PV installations, clients prefer to buy Chinese-made solar components. This is especially the case for large-scale solar projects where the number of solar modules is so large that a small difference in the price for a single module can affect the final cost of the project in the range of hundreds of thousands or even 
millions of US dollars.

The rivalry between the two countries in the solar sector began back in 2008 when China stepped out on the global solar market and started producing mass quantities of solar PV components. The situation kept escalating and in 2012 the US International Trade Commission imposed a series of anti-dumping and anti-subsidy duties on solar PV components made in China with some as high as $250 \%$ on the original price [31].

Despite the anti-dumping and anti-subsidy taxes, however, the bulk part of the solar installations in the US today are still being carried out with imported solar components. According to PV Magazine, from 2012 to 2016 solar imports in the US saw a five-fold increase while at the same time there was a rapidly growing demand for solar PV modules on the local market. As a result, the imports captured "virtually all of the 350 percent increase in US demand" while at the same time "imports from China increased some 732\%" [32] for the same period of time.

In brief, the solar sector in the US has seen a significant development in the past but for a number of reasons it didn't have the impetus this industry received in China. Because of this, the Chinese solar industry has accumulated a significant advantage compared to its American competitors, and this has laid the basis for the Sino-American solar trade frictions we are witnessing today.

\subsection{The Research}

The present study is based on the concept that climate change is real, it is human-induced and the consumption of fossil fuels is one of the most important factors exacerbating the problem. The same position was expressed by the previous US president Barack Obama and the Chinese President Xi Jinping in a joint statement for addressing the issue of climate change. The two presidents took a clear stance on the question agreeing with the scientific community that the Earth's atmosphere is warming up, leading to changes in the global climate and that human activity is the main contributor to this that process:

"The global scientific community has made clear that human activity is already changing the world's climate system. Accelerating climate change has caused serious impacts. Higher temperatures and extreme weather events are damaging food production, rising sea levels and more damaging storms are putting our coastal cities increasingly at risk and the impacts of climate change are already harming economies around the world, including those of the United States and China. These developments urgently require enhanced actions to tackle the challenge." [33]. The announcement also underlines the importance of the Sino-American collaboration for tackling climate change and envisions a large-scale deployment of low-carbon energy technologies, including the solar PV technology.

In the present essay I examine the solar energy's deployment as a way to tackle the issues of climate change while at the same time contributing to the economic growth [34]. I argue that from the perspective of International Relations, renewable energy can be perceived as means for deepening international collabo- 
ration without giving rise to disputes.

The current research examines how the solar energy industry can be utilized as basis for cooperation between China and the US without creating any grounds for confrontations. It gives recommendations on how to enhance the $\mathrm{Si}$ no-American cooperation through solar energy projects without exacerbating the existing solar trade disputes.

\subsection{The Significance of the Project Selected}

The introduction of the essay examines closely the Sino-American solar trade frictions and the main exposition presents a number of suggestions on how to create future projects of collaboration which can bypass any points of potential disagreements between international actors. To achieve this, I study in detail the joint solar energy projects between Apple and Sun Power as an example for successful cooperation between an American and a Chinese-operating company [35]. Based on the characteristics of these projects, I draw conclusions regarding how future joint projects between countries should be structured in order to encourage cooperation and minimize trade frictions.

The series of projects between Apple and Sun Power were used as a backbone of this research because of the strong impact they have had on the $\mathrm{Si}$ no-American collaboration in the solar sector. It is important to note that this is one of the first examples for joint solar projects between an American and a Chinese-operating company. After the first part of the project proved to be very successful, the collaboration continued and the scope of the following projects kept expanding. From two solar farms with 20 megawatt peak capacity each, to a new project with 400 megawatt peak capacity, followed by a third project with 2 gigawattpeak installation capacity (100 times bigger capacity than the first one.)

The exponential growth of the Apple-Sun Power solar projects speaks alone for the success of this endeavor. Furthermore, the collaboration between the two companies has played yet another important role: it has served as a test project for the future of Apple's business development. In 2016, not long after the first solar projects proved to be a success, Apple, famous for its electronic smart devices, announced that it is going to expand its business in the area of solar energy [36]. This can be viewed as another proof for the growing importance of the solar sector and the impact it is having on different industries around the world.

The Apple-Sun Power collaboration can also be observed as an undertaking which laid the basis of Apple's expansion in the solar industry. It has also paved the way for collaboration between Apple and other companies in China for the creation of more solar projects. Such example is another solar power project which Apple is building together with Foxconn in China [37]. This comes to show the importance of the Apple-Sun Power solar projects and the role they have played in setting an example for similar initiatives in the future.

From an International Relations perspective, this series of projects can be viewed as basis for a successful Sino-American collaboration and a way to pro- 
mote peace between international actors without creating any grounds for confrontation. I analyze the specific features which make this collaboration successful, and based on these findings I present a list of suggestions which can potentially serve as a guide for policymakers to create future projects which could promote peaceful collaboration between the US and China. Additionally, this approach can potentially be applied to other countries who wish to promote their national solar industry and their peaceful relations with other actors on the international arena.

\section{Case Study: The Apple-Sun Power Joint Solar Projects}

\subsection{Apple in China}

There are many foreign companies which have based part or even their entire manufacturing strategy in China. This approach has proven to bring a number of benefits for the companies which apply it but at the same time it contributes to the environmental degradation and air quality problems at the manufacturing location. Since all manufacturing processes require energy and in China energy is mainly derived by coal and other fossil fuels, some scholars argue that foreign companies in fact stand in the roots of the air pollution problems in China [38].

The American company Apple also has a considerable volume of its product's parts manufactured and assembled in China [39] [40]. However, in comparison with other companies of a similar scale, in the last few years Apple has adopted a much more responsible approach to its manufacturing in China. As a way to achieve that, the company has focused on investing in the local solar industry and promoting clean energy. Hence, Apple, in collaboration with the solar company Sun Power started constructing solar power plants which produce enough electricity to offset a considerable part of its energy consumption. In this way, the carbon footprint of Apple's operations is reduced significantly to the benefit of the local environment and the local air quality.

This step shows a much more conscientious approach towards conducting business in China, especially at a time when air pollution and environmental degradation have become sensitive issues in this country. The clean energy strategy undertaken by Apple comes as a solution to the abovementioned problems. It is a way to reduce significantly Apple's impact on the local environment by offsetting the energy used in its offices and retail stores. This helps the company curb its carbon emissions, reduce its electricity expenses and bring benefit to the local community where the projects have been developed. This approach can potentially be used as an example for conducting a "cleaner" business in China as well as in any other part of the world.

\subsection{The Solar Projects}

By 2017 Sun Power has completed two projects in cooperation with Apple: 1) two 20 megawatt solar power plants in Sichuan (completed in 2014) and 2) one 400 megawatt solar plant in Henan. Another project with installation capacity of 
2 gigawatts is being planned in Henan province.

Currently, the solar electricity generated by the functioning projects off sets the amount of energy used to power Apple's offices, data centers and retail stores in China. In this way, Apple is reducing its carbon footprint and is contributing to the global efforts for bringing down carbon dioxide concentration in the Earth's atmosphere while at the same time is investing in the Chinese solar industry,

Reduction of the carbon footprint concentration is possible thanks to one key characteristics of the solar energy technology: the solar power plants don't create any emissions during electricity generation and because of this the solar technology is considered one of the cleanest means forenergy generation. For this reason, Apple has set a goal to power $100 \%$ of its manufacturing and services with renewable energy (with solar energy being a priority) and at the same time is pushing its suppliers to take steps in the same direction. In short, solar energy is helping the company achieve its goal for becoming carbon-neutral while at the same time keeping its stable functioning and high manufacturing volume [41].

From an International Relations perspective, these projects represent an interesting case study. This is because they stand out with the number of positive effects they bring in the midst of a complicated trade situation between China and the US in the solar energy field. Indeed, despite a long and constantly deteriorating solar trade dispute between the two countries, the American company Apple and the Chinese-operating Sun Power [2] have found a way to develop together solar energy projects without causing any frictions between the two sides. Moreover, this has sets the ground for cooperation on a whole new platform to which all people, governments and businesses can relate: the fight to curb global carbon emissions and slow climate change.

\section{Strategy for Carbon Neutrality}

In 2014 Apple started investing in solar power stations in China which were constructed by Sun Power and today are co-owned by the two companies. The electricity produced by these projects has zero carbon emissions and because of that it compensates for the carbon footprint produced by some of Apple's operations. However, it is not being used directly by the company but is being fed into the local electricity grid. In this way it offsets part of the energy consumed by Apple without bringing with itself the harmful impact of fossil fuel consumption.

In order to do so, it has been calculated how much electricity is being consumed by each type of Apple's operations and how much electricity the solar power plants will be feeding into the grid. In this way, it has been estimated that the $40 \mathrm{MW}$ project in Sichuan is producing enough power to offset the power consumption of all Apple's offices and retail stores in China and in this way offset a considerable part of the company's carbon footprint [42]. This constitutes a big step towards making Apple a carbon neutral enterprise [43] and according to 
Apple's agenda it will later be followed with turning the company's device assembly processes $100 \%$ dependent on solar-generated electricity [44].

Furthermore, Apple is not the only one who benefits from the solar projects: the local people in the area who don't have access to the conventional grid use the electricity produced by the solar power plant. This shows yet another advantage of the solar PV energy: the opportunity to bring electricity to small communities in remote locations where connection to the conventional grid has not been established [45].

\subsection{History of Apple’s Solar Projects}

In 2012 Apple started diversifying its energy supply with electricity generated by solar power plants. The company started a project which aimed at making all of its operations $100 \%$ dependent on energy generated by solar. The first step of the project was to build a solar power plant in Nevada, USA [46]. Four years later, in 2016 Apple has achieved the goal of powering 100\% of its data centers in China, USA and 21 other countries entirely from renewable energy [47].

With its Nevada solar power plant built in 2012, Apple can be considered a pioneer in the solar power sector. Since then, the solar photovoltaic industry has undergone a dramatic development which has made it very attractive for investors. However, when Apple stated committing to solar energy back in 2012, the prices of electricity generated by solar was much higher than today. Therefore, at the time of the Nevada project construction, such investment was considered a risky endeavor and a step inspired merely from concerns for the environment, leaving behind any possibility for financial gain. Nevertheless, the project proved to be economically feasible for Apple and paved a way to a future where solar energy is becoming increasingly important.

\subsection{Apple's Solar Projects in China}

After China's economic transformation in the late 70s, when core economic reforms started being implemented, it became the biggest global manufacturing center for almost all products available on the market. However, since coal and other fossil fuels constitute the main source of energy in China, the massive scope of industrialization which, of course, requires a lot of energy, has taken a toll on the local environment. This has resulted in heavy air pollution in industrialized areas and has become one of the most pressing issue the country is facing [48].

Apple, on the other hand, has set an example for a completely new approach towards production in China: instead of relying on coal and other fossil fuels to obtain its energy for production and production-related services, Apple has built its own solar power plants and has cooperated with local solar energy companies in the process (projects in Sichuan and Henan, China). This has resulted inconsiderably lower carbon footprint, zero air pollution during energy generation and immensely reduced impact on the environment. 
Thanks to these projects, China can continue to be the base of production and assembly center of Apple's products without having to endure environmental degradation. This represents a completely new approach to overseas businesses conduct and for several years now it has proved to be an absolute success. For instance, it has been calculated that the solar projects will save over 20 million metric tons of greenhouse gas emissions in China between 2014 and 2020 [49]. This is equal to taking 4 million internal combustion engine cars off the road for one year. To support this data Apple issued an Environmental Responsibility Report showing the contribution which its solar power installationsin China are already making. According to the report the $40 \mathrm{MW}$ projects have reduced the emissions from Apple's offices, data centers, and retail stores around the world, in this way preventing more than 1.6 million metric tons of $\mathrm{CO}_{2}$ from entering the atmosphere [50]. Using solar energy proves a successful strategy to reduce the emissions while at the same time allowing the company to expand its activities and grow. This is visually represented in the following table:

The table shows how Apple's emissions are diminishing with time while from the same report we know that the company's production and services are rapidly growing. The graphs with dotted lines represent how high the company's emissions would have been if the solar projects in China had not been built. Thanks to these projects, between 2011 and the end of in 2016, the $\mathrm{CO}_{2}$ emissions from Apple's offices, data centers, and retail stores were reduced by 1.6 million metric tons.

Indeed, this number is still far from the abovementioned estimations for 20 million metric tons which the projects are expected to reduce from Apple's activities by 2020, but this doesn't mean that this estimation is wrong. Here it is important to note the following: 1) The estimations represented in Figure 4 are based on solar power plants with installation capacity of $40 \mathrm{MW}$ and it is not taking in account the $200 \mathrm{MW}$ power plant in Hebei, China, which is expected to be activated in 2018 and the $2 \mathrm{GW}$ power plant which is still under construction. 2) The 1.6 million metric tons $\mathrm{CO}_{2}$ saved from being released in the atmosphere represented in Figure 4, are emissions only from Apple's offices, data centers, and retail stores. Right now Apple is working on a way to make its manufacturing processes also environmentally-friendly and urge its suppliers to do the same. Since the manufacturing requires much more energy than the functioning of the offices, data centers, and retail stores, it is possible that if Apple's strategy succeeds, the estimation for 20 million metric tons $\mathrm{CO}_{2}$ being saved from entering the atmosphere by 2020 , could very well come close to the real numbers in 2020.

Apple's Environmental Responsibility Report shows that the strategy for using solar-generated electricity instead of electricity from the conventional grid proves to be a successful way to lower carbon emissions while at the same time allowing the business to grow. Such development not only benefits the companies Apple and SunPower but also creates a win-win situation for China and the US in terms of investment and business opportunities. 


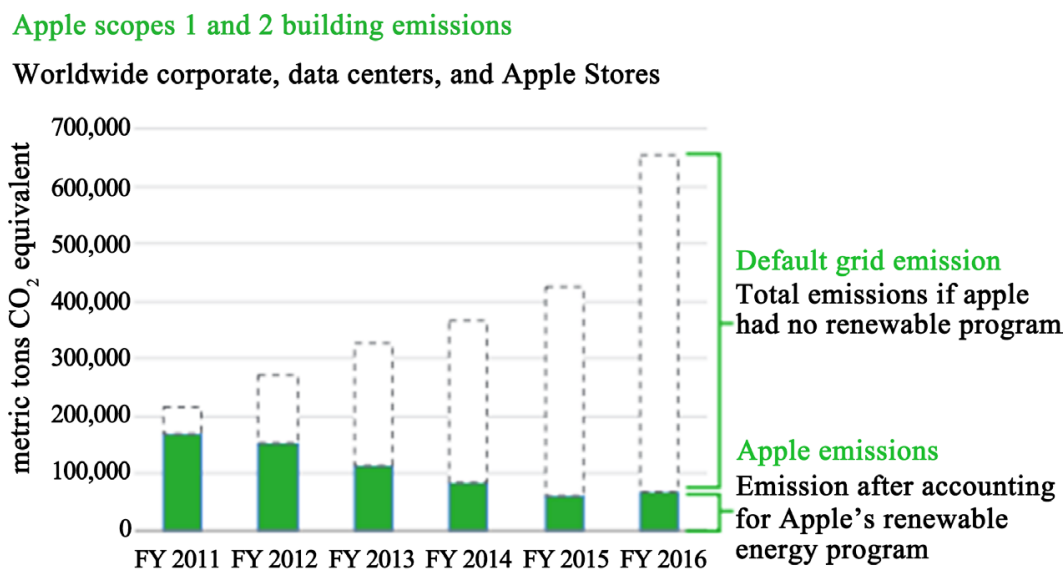

Figure 4. The amount of Apple $\mathrm{CO}_{2}$ emissions saved from being released into the atmosphere thanks to the functioning of the solar power plants built in China [51].

In short: the projects are environmentally-friendly, don't pose threat to the local ecosystem and bring benefit to the local community by providing electricity to isolated areas which have not been connected to the conventional power grid.

Apple and Sun Power achieved this thanks to two joint projects: a 40 megawatt solar power plant in Sichuan province (comprised of two solar plants with 20 megawatt capacity each) and a $400 \mathrm{MW}$ plant in Henan province. This enterprise proved to be so successful that Apple is planning to build another project in China: this time with capacity of 2 GW (100 times bigger than the first solar plant in Sichuan.) [52]. Learning from the latest technological and business trends around the world, Apple has started to diversify its business by entering the solar sector, while continuing to install more solar projects in China.

\section{New Technology}

The Nevada solar power plant can be considered as Apple's first step in the solar sector. These projects have helped the company accumulate experience which it later used to experiment and improve the following projectsbuiltin China. As the researches Katie Fehrenbacher points out, the solar farms created together with Sun Power are quite innovative and show a considerable technological upgrade. In their construction a new type of technology was used, the so-called hybrid solartechnology: a combination of concentrated solar and photovoltaic solar technology. The projects are designed with special mirrors used in the concentrated solar plants which focus the light on the solar PV panels. In this way, the solar PV panels convert the concentrated sunlight into electricity more efficiently and produce more power on a smaller surface [49].

The case of Apple collaborating with Chinese solar companies is also a very good example of how technology trespasses national borders and can be used for the benefit of all. Analyzed through the prism of International Relations, it can be viewed as a way to create win-win situation for China and the US by promoting their solar industry and bringing benefits to the investors. It represents a bilateral project that can potentially serve as a model for future collaboration be- 
tween the two countries not only with respect to the solar industry but also in many other areas.

\section{Characteristics of the Apple-Sun Power Projects}

Analyzing the number of benefits brought by the Apple-Sun Power joint projects and considering that it has not given rise to any frictions on state level or between businesses, one can safely conclude that this type of collaboration is having a positive impact on the overall relationship between China and the US.

This series of solar power stations is something unique of its kind and could be used as a blueprint for other projects between the two countries to promote bilateral collaboration. Moreover, this type of projects can be applied between other countries as a way to stimulate their solar industry and promote cooperation with other actors in the international system.

But first, in order to be able to use the solar projects between Apple and Sun Power as a model for building international collaboration, it is important to note some of the projects' main characteristics. Here is a list of some of their most prominent characteristics:

1) The projects are a collaboration between privately-owned companies;

2) The projects do not include trade of solar photovoltaic products;

3) The projects do not give rise to trade disputes;

4) They create a win-win situation;

5) They bring benefits in a relatively short period;

6) They are built in accordance with environmental policies crafted in both countries;

7) They promotea sustainable economy;

8) They benefit non-active participants (local people);

9) They have minimum impact on the environment;

10)They are developed in one designated location;

11) They do not need direct involvement from any government;

Given the success of the projects, I believe that their characteristics may be a key to building optimal cooperation between China and the US and promote peace between the two countries and in the entire world.

As noted earlier, trade conflicts in the solar sector are easy to emerge, especially between countries which are leading investors and installers of solar technology such as the US and China. Nevertheless, the collaboration between Apple and Sun Power have found a way to bypass the trade of solar PV products. One key reason may be the fact that the components used in the projects are manufactured locally and therefore, there is no need to import them. This feature saves the project participants from facing any trade disputes and in this way sets a positive example of how future solar projects between countries should be conducted.

The Apple-Sun Power projects have a number of characteristics which deserve to be analyzed in detail. Here I have focused my attention mainly on two of them: the quick return of investment and the big number of benefits they have 
brought about. These two factors, in my opinion, hold the key for the success of the Apple-Sun Power collaboration.

\subsection{Key Feature: Quick Return of Investments}

Previous agreements for collaboration in the renewable energy sector between China and the US have been instigated by concerns for energy security and environmental preservation. The benefits from such agreements, however, usually don't consists of direct financial profit but promise obscure benefits expected somewhere in the distant future. These efforts for collaboration are mostly perceived as a way to help the environment and the humanity as a whole but not to bring direct profit for the companies involved. Such examples are the $1979 \mathrm{Me}-$ morandum of Understanding (MOU) for Bilateral Energy Agreements and a number of bilateral agreements on renewable energy between the US Department of Energy and the Chinese Ministry of Agriculture signed in 1995 [53].

As altruistic as it may be, this type of collaboration often stays only in the political realm without being effectively executed. This is mainly because such political endeavorslacks clear plan for generating revenue; and since the revenue is a crucial element for the existence of any company, projects which don't have a clear plan for how it will be generated, are not appealing to most businesses entrepreneurs. Therefore, most of these agreements remain at the stage of planning and only serve as show of good will while in reality they cannot show any actual accomplishments.

In this regard, the cooperation between Apple and Sun Power shows a new approach towards the cooperation in the renewable energy sector: it creates projects which generate actual profit (for Apple this comes in the form of cheap electricity and for Sun Power in the form of investment) and return of investment in a short period of time. This makes solar power projects economically feasible and an appealing opportunity for investment from point of view of the participants. For example, Apple has invested more than USD 103 million for one of the joint projects with Sun Power [54] after contributing with more than USD 850 million for a solar farm in California [55]. In addition, a solar power plant can start generate profit in the form of electricity immediately after the project has been completed. This can be possible even if only one part of the construction has been completed [56], further cutting down the time necessary before profit can start to be generated.

\subsection{A Number of Benefits}

The collaboration between Apple and Sun Power has brought many benefits from economic as well as from environmental point of view. Here is a list of some of the most notable ones:

1) The solar power plants generate clean energy which offsets the power consumption of all Apple's stores and offices in China;

2) The generated solar power will save over 20 million metric tons of green- 
house gas pollution in China between 2014 and 2020;

3) There is a direct contribution to the Chinese solar industry in the form of investments from Apple to Sun Power;

4) Apple is saving money by accessing cheap electricity;

5) Apple is using the projects as a good way to brand its name as an environmentally friendly enterprise;

6) There is cheap zero-carbon electricity produced for the company's functions and for the local people to use directly;

7) Sun Power is innovating its solar technology in the process;

The listed above can be considered as "visible" results since they can be measured in terms of money which has been saved, money which has been invested or amount of carbon dioxide which has been prevented from going into the atmosphere. They come to show that projects in the renewable energy sector can be made in such way that they generateprofit, they can achieve it in a short period of time, create a win-win situation and can be beneficial both from an economic and an environmental perspective.

The joint projects bring also other benefits which are hard to be measured but are nevertheless important. For example the impact of the Apple-Sun Power projects on the overall relationship between the US and China. By setting a good example of cooperation in the solar energy sector, these projects are having a positive impact on the relations between the two countries. In fact, the first phase of the collaboration has proved so successful that it has led to Apple building a new $400 \mathrm{MW}$ project in Henan province and the planning of a new solar power plant with generating capacity of $2 \mathrm{GW}$.

Because of the unique features of this collaboration and all its achievements, I argue that the Apple-Sun Power solar energy projects can be used as a model for creating future solar energy projects between other companies from China and the US. It can potentially be extended to companies from other countries as well. This can create incentives for investment, push forward the technological development in the solar sector and push forward the solar industry in each country-participant. In the same time, such initiatives promote peaceful international cooperation, help governments and enterprises on both sides work together and promote their domestic solar industry while at the same time create innovations in the solar technology.

As we see from the Apple-Sun Power example, the advantages from such collaboration translate not only in direct economic benefit but also in terms of environmental preservation. They promote sustainable development and help address the issues of climate change-two of the most pressing issues in the modern era. Indeed, it is hard to estimate precisely the monetary benefit of this collaboration. Nevertheless, it is obvious that they bring considerable economic benefit which will keep growing with time.

\section{Lessons from the Apple-Sun Power Solar Energy Projects}

In the last few years, the big quantity of Chinese solar PV imports in the US have 
caused disturbance on the American market. As a result, Washington reacted protectively to its national solar industry, imposing import tariffs on Chinese solar PV components [57]. This situation has created tensions which could potentially have a negative impact on the economic relations between the two countries. On the other hand, the solar industry is a good way to create a sustainable economy and eliminate the dependency on fossil fuels. For this reason, it is important to find a way to promote the cooperation between China and the US in the solar energy sector without causing damage on the economy of either of them.

Deriving conclusions from the cooperation between Apple and Sun Power, I conclude that there are several aspects which mark a successful project in the solar PV industry. I believe they can serve as a blueprint for establishing other projects of collaboration between countries for the benefit of the environment and the peaceful relations on the international arena. The following is a list of key features which I argue are imperative for creating a successful international collaboration in the solar sector:

\section{1) There should be a win-win situation}

The cooperation between Apple and Sun Power is a good example for cooperation between the US and China in the solar energy sector. It creates a win-win situation for both participants: from one side Apple benefits from the relatively cheap labor force in China and cheaper electricity bills; on the other side is Sun Power which receives investment and support for technological innovation. Additionally, part of the energy generated by the solar power plants is being used by local people who do not have access to electricity otherwise. In this way, the joint projects bring benefit to both parties involved, as well as to the local community and the environment.

2) The projects should be carried out on a local level without engaging in a cross-border trade of solar PV components.

In contrast to conventional solar PV trade which has created a number of disputes between China and the US, the cooperation between Apple and Sun Power does not include one essential element: trade flow of solar PV products. The projects are being developed with the use of local components and eliminate the need for import. Taking in account the success of these projects and the plans for their further expansion, one may conclude that taking solar PV products trade flow out of the equation might be a key element for building successful collaboration between China and the US in the solar sector.

\section{3) Quick return of investments}

There are numerous international agreements on tackling environmental degradation and climate change. The agreements regard the reduction of carbon emissions as a key factor for achieving the set goals. One such example is the China-US Environmental Cooperation Strategy which promises joining efforts from both governments in order to lower carbon emissions and hence: slow climate change [58]. 
However, more often than not, this means shutdown of coal-fired power plants or upgrading these plants in order to minimize their carbon footprint. This translates into reducing energy generation and the need for huge investments in the facilities. Therefore, instead of revenues, these agreements imply huge expenses for the countries-participants.

Indeed, there is the expectation for some economic benefits but often they are not guaranteed and are expected to be achieved in the span of decades. Such benefits most often include: better air quality, improved health of the population, less expenses on healthcare, lower concentration of $\mathrm{CO}_{2}$, slowing of the climate change processes, etc. These results could be expected after years of joint efforts and moreover-it is difficult to make a guarantee of the actual result. This makes the goals of environmental agreement obscure and gives rise to doubts whether such collaboration would have the promised effect.

In the example of Apple-Sun Power joint projects, however, the benefits can be seen after a short period of time: there is a direct investment from Apple to Sun Power and immediately after a part of the project has been completed there is electricity generated and fed into the grid. Additionally, the electricity expenses for Apple are significantly reduced since the price of the solar electricity from these projects is half the price of the conventional electricity [49]. At the same time, the produced surplus of electricity is directed to the homes in the area so that local people can also benefit from the projects. For the above reasons I argue that the quick return of investment is a key feature we should take in account when planning joint solar projects between countries.

4) The projects should have positive impact on the environment and the society

Indeed, environmental collaboration often cannot guarantee economic benefits; nevertheless, Beijing and Washington are still dedicated to lowering carbon emissions and create a cleaner economy. This is the so-called "no regrets" policy according to which certain governments agree to pursue goals which can potentially benefit the environment and the human population as a whole without the guarantee for any financial benefits for their country. Despite that, it is still a popular endeavor because even if there is no direct cash inflow as a result of this collaboration, in the long run there are going to be a number of positive impacts which can be equated to economic benefits. This is because when the global environment is being protected and a sustainable economy is being created, the benefits will be obtained in the form of cleaner air, soil and water, healthier population, less spending on healthcare, potential climate disasters being avoided, many new jobs in the related industries being created, protection of the biodiversity and many others.

Indeed, the projects between Apple and Sun Power have proved to be both environmentally friendly and economically beneficial. This is because they assist the global efforts for fighting climate change while at the same time they provide immediate profit for both participants: Apple receives electricity at half the price and Sun Power profits from Apple's investment and in novates its technology. 
Additionally, the local people have a guaranteed access to electricity which is low-cost and environmentally friendly.

Except for material profit, this project brings a number of benefits which cannot be observed directly but have an overall positive impact on the environment and the global population. In the same time, Apple can continue its regular functioning and even meet the growing energy demand without causing harm to the local environment.

In short, learning from the cooperation between Apple and Sun Power I conclude that there are several main features which make one solar project successful in promoting international collaboration:

1) the projects should be carried out on a local level without engaging in a cross-border trade of solar PV systems;

2) the projects should guarantee quick return of investment;

3) all participating sides should be able to obtain benefit;

4) a successful project should also bring positive impacts on the global environment and the society in the long run.

Keeping in mind these characteristics when planning joint solar projects between countries could help successfully promote international cooperation and peace while at the same time pushing the economy forward. This is possible because such projects are profitable for all participants, they guarantee quick return of investment, bring numerous benefits and last but not least: they allow economic growth without taking toll on the environment.

\section{Transition to a Low-Carbon Economy}

The contemporary economy is based on the pursuit of constant growth [59]. This in turn translates into higher demand for energy and consecutively-increase in consumption of fossil fuels. But as the majority of the scientists have warned us, this constant energy demand is having a huge impact on the environment and for this reason it is not sustainable [60].

\section{1) Production with Minimum Impact on the Environment}

Similar to the global economic growth, Apple's energy consumption has also been growing rapidly. As number one company in the world it has a very high energy consumption and according to its analysis, in the last three years this consumption has grown by $42 \%$ [61].

In order to meet its increasing energy demand in an environmentally-friendly way, the company has dedicated efforts to build several solar power plants to offset the energy consumption of its offices and data centers. This step was taken because solar energy has proved to be a good alternative to fossil fuels and a way to meet a growing energy demand without the harmful effects on the environment [62]. Apple has come to realized this as early as 2012 when it started building solar power plants in the US to power its operations. A few years later, thanks to the global commitments to solar energy, the prices of electricity generated by solar have been plummeting with up to $50 \%$ a year [63].

According to the latest report from 2016, $96 \%$ of the electricity used by Ap- 
ple's facilities around the world came from renewable energy, reducing the company's carbon emissions by 585,000 metric tons [64]. Additionally, all Apple's operations in 24 countries are $100 \%$ powered by renewable energy and the same applies to all of Apple's data centers [65]. The energy is a combination of renewable energy the company buys and on-site generation capacity from which solar constitutes the biggest share.

This strategy was initiated in 2013 when Apple started powering all its data centers with solar energy and then it expanded the scope to its factories, service centers and stores which constitute the whole chain of production and services. Now Apple is advancing its agenda on solar energy by urging its suppliers in China to make the same commitment [66].

The answer from the Chinese companies has been positive and many of them are making the transition to solar energy. In addition, Apple's interest in the solar technology is coming at a moment when the solar sector in China is expanding at a fast rate. This can potentially translate into a great stimulus for the Chinese solar energy sector because of the strong position Apple holds as the biggest company on the global market.

Apple has a long list of production and assembly plants all over the world, predominantly in China [67]. For this reason, by asking its downstream suppliers to include solar in their energy mix, the company can exercise strong positive influence on the Chinese solar market.

\section{2) Future with More Solar Energy}

Solar energy has proved to be an efficient, cheap and environmentally-friendly source of energy. However, as is the case with any product on the market, there is a certain carbon footprint left by the production process of the solar photovoltaic panels and all solar components. Nevertheless, the panels offset these carbon emissions in the span of just two years of functioning [68]. Furthermore, the growing production of solar panels drives down the price of electricity produced by solar. The falling electricity price further promotes the proliferation of solar energy and can potentially help the global economy meet the ever growing energy demand without causing environmental degradation and global warming.

In this regard, Apple has set a positive example for how the increasing energy demand can be met with solar energy and in this way create a sustainable growth. Apart from the analysis showing $42 \%$ increase in the energy consumption in the last three years, the company has estimated that its power consumption in the future will continue growing with a similar pace: around $45 \%$ increase between 2017 and 2019 [66]. Thanks to the solar power plants, however, the company will meet this demand and continue to be carbon-neutral.

\section{3) Apple's Impact on China's Solar Industry}

In 2012 when Apple started investing in solar energy, the prices of electricity generated by solar were much higher compared to the conventional electricity. It was not economically feasible and therefore very few companies were investing 
in it or trying to make solar energy part of their energy mix. Despite the apparent lack of economic sense, however, Apple started investing in the solar market by paying voluntarily extra for electricity generated by solar [49].

In this way the company started promoting this type of energy and in 2012 even built its own solar farm in Nevada, USA. Just a few years later, in 2017 we see that solar energy rapidly is becoming more and more widespread across the globe, especially in China and the US. As a result, the prices of solar-generated electricity are plummeting globally and in many places around the world solar electricity is approaching or has already reached grid parity. This phenomenon has also helped Apple to save money on electricity: compared to prices on the conventional grid in the US: 0, $10 \mathrm{USD} /$ kilowatt hour, in China Apple is paying half that price: $0,5 \mathrm{USD} /$ kilowatt hour with projections that the price will continue falling. This creates a win-win situation for Apple and Sun Power and sets yet another example from which China and the US can learn how to build cooperation and benefit together from the solar energy sector.

Apple's solar energy projects in China have proved to be a successful endeavor. They have even reached a point where the electricity production has exceeded the demands of the company and for this reason they are utilizing the excess energy to power the homes of local families [52]. In this way the Apple-Sun Power joint projects create benefits for the local people and show another positive characteristics of the solar energy: it can be used in remote areas which do not have access to the conventional grid.

Furthermore, the collaboration between Apple and Sun Power has helped both companies grow and become more competitive on the market. Sun Power has noted that the collaboration with Apple has pushed them to innovate and develop further their technology [49]. We see a proof for that in the solar power plants in Sichuan and Henan: there, the concentrated solar and photovoltaic solar technology have been combined to produce higher power output from a smaller land surface, making the power plants more efficient [66].

The projects between Apple and Sun Power have created a win-win situation for both companies and thanks to Apple's investment and push for innovation, have also benefitted to a certain extent the Chinese solar industry. Therefore, one can well say that this type projects can serve as an example for future collaboration between Chinese and American companies which in turn can potentially promote the peaceful relations between the US and China.

\section{4) Global Transition to a Green Economy}

In the last few years in the agenda of many companies and governments around the world there has been a growing interest towards renewable energy. This has translated in the notion of "green economy" or "low-carbon economy": the idea for using renewable energy instead of fossil fuels to generate electricity and power the global economy [69].

In this way, the manufacturing and services don't have to slow down but at the same time the carbon footprint would be considerably lower compared to using electricity from conventional resources. This means that the inevitable 
impact on the environment will be minimized; there will be considerably lower levels of air pollution and concentration of carbon dioxide. There are many signs for this transition taking place all around the world and one may argue that this is a natural result from the deployment of renewable energy, more specifically: solar energy.

Regarding the possible transition to a low-carbon economy, China and the US are leaders in pushing forward this agenda. Both countries are leading in manufacturing and installation of solar PV systems, both governments are promoting solar energy in a number of ways and there are many projects for collaboration between them in the area of solar energy. In this way China and the US are helping each other develop further their domestic solar energy industry and possibly make a transition to an economy entirely based on energy from renewable resources.

The latest development in the work between the American company Apple and the Chinese-operating company Sun Power is a proof that such major shift in the global economy is taking place right in this moment. Their collaboration represents the building of a number of solar energy projects with each project having bigger generating capacity than the previous one.

From point of view of International Relations, this can serve as a good example for the US and China working together to promote the solar energy deployment. Working in partnership with Sun Power, Apple has built two 20 MW solar power plants just in China. Also, thanks to this partnership, a solar PV plant with generating capacity of $400 \mathrm{MW}$ is being constructed, and Apple has announced plans to install more renewable energy projects with generating capacity of more than $2 \mathrm{GW}$ [70].

This collaboration is promoting the manufacturing of solar panels and thus is helping boost up China's solar industry. It is expected that after not too long, the major part of the energy generation in the two countries will shift from fossil fuels to renewable resources and this will help China and the US become low-carbon economies. In order to achieve that, however, the two sides should first deepentheir collaboration in the solar energy sector by minimizing the trade disputes which are hampering the development of the Sino-American ties at the moment.

\section{Promoting Collaboration between China and the US in the Solar Energy Sector}

In the last few years energy security and environmental protection have become two of the most pressing issues for many countries around the world. The impacts of climate change for which scientists have been warnings us for decades have become increasingly difficult to ignore. This, together with the increasing energy demand on a global scale, has raised concerns on how to maintain economic growth and at the same time not exacerbate climate change.

Many governments, including China and the USA, have taken these issues into serious consideration and have started to create policies which will help them 
face the challenges of the future. As the two biggest economies and the two largest energy consumers, China and the US regard energy diversification and environmental preservation as top priorities on their agenda. They have crafted a number of projects and policies which will help them secure their access to energy and at the same time slow down climate change. In the core of this shiftlies the development of renewable energy technology with solar energy being a priority.

Renewable energy technology is a proven way to harness energy from the natural resources without causing environmental degradation. This approach can potentially become the solution for the two main challenges of the modern world: energy security and environmental preservation. In the last few years, solar energy is the renewable resource which has become the focus of attention from many companies and governments around the world. In this regard, China and the US are the two most notable examples. The joint projects between Apple and Sun Power can be taken as model on how to promote the Sino-American collaboration in the solar sector and hence: the overall stability in the international system.

The solar energy sector presents many opportunities for collaboration. However, the ongoing conflict between China and the US regarding solar PV imports from China show that solar energy can also provoke disputes [71]. Therefore, it is important to take such disputes into consideration when creating future projects for collaboration in the solar energy sector.

Henceforth, analyzing the successful projects between Apple and Sun Power, I have listed a number of suggestions that can potentially promote the global solar energy deployment without giving rise to conflicts between the participants.

\section{Suggestions:}

\section{- Protect the technology and create incentives for scientists to innovate}

Technological exchange plays a crucial role in the Sino-American relations. In some cases it promotes collaboration but in others it becomes the ground for disputes. For example, many specialists have expressed concerns that in cases of joint ventures between Chinese and American companies, there has been a transfer of technology from the American companies to the Chinese counterpart. This has been the main reason why many innovators from the US have abstained from forming joint ventures with Chinese companies. (One such example is Elon Musk and the electric vehicle company Tesla.)Because of this, it sounds only logical that American companies should be granted full copyrights on their own technology as a way to make them more willing to take part in joint ventures with Chinese solar companies. Therefore, when participating in a joint venture together with American companies, the Chinese side should guarantee that the technology of its American partner will not be transferred to other companies or if it is transferred, the companies wishing to use the technology, should pay copy rights.

Despite the disputes which it gives rise to, the sharing of technological know-how has crucial importance for the world as a whole. It helps the flow of 
ideas and the innovation of the technology. For this reason, presenting the new technology in a way by which everyone can see the creators, can to a certain extenthelp the scientists receive recognition for their invention and possibly help them keep the copyrights. This could be done on science fairs and TED talk-like events where each participant can present their discovery and receive recognition for it. In this way scientists can meet together to discuss ideas while being guaranteed that their contribution will be noted and they will receive benefits for their efforts.

- In international projects, one part of the elements should be produced in one of the countries and part in the other country-participant.

Taking as an example the conflicts between Chinese and American solar companies, I suggest that the solar products should be manufactured in both countries which participate in the project.

This can be achieved through policies, laws and regulations which both sides agree to follow. It should also be taken under consideration that the benefits from the projects should be divided between the participants and each should receive their fair share.

\section{- Create more project of collaboration between different countries}

As mentioned above, collaboration between countries helps the innovation of the technology and has a positive impact on the overall relationship between the countries-participants. The Apple-Sun Power project in Sichuan is a good example for a project which promotes collaboration between companies from two different countries without giving rise to conflicts. Some of its characteristics include: development of projects locally, no cross-border trade of solar PV products, guaranteed profit for all participants, quick return of investment and no harm inflicted on the environment.

In my opinion, these are the basic requirements a solar project between two countries should have in order to be successful. Furthermore, copyrights protection, sharing technology, creating environment for scientists to innovate and policies which overcome the solar trade disputes, can promote to a great extent the cooperation between solar energy companies all around the world. This, on the other hand, can become basis for developing cooperation in other sectors and can potentially help promote peace on the international arena.

- The Projects Should Have a Positive Impact on the China-US Relations

Solar energy has a number of characteristics which make it a suitable ground for cooperation between countries: it is a renewable resource of energy available all around the globe, the components are easy to acquire and most importantly, it is an eco-friendly way to generate electricity. Furthermore, such cooperation creates a complex interconnection between the participants by bringing them to collaborateon different levels and work toward sonecommon goal.

Nevertheless, in the case of China and the US - the global leaders in solar photovoltaic manufacturing and installation-solar energy has become the reason for some trade frictions. Therefore, if joint solar project are to be used as a way to promote cooperation between countries, they should be planned carefully 
in order to minimize any possible negative effect which can potentially harm the bilateral relations of the participants.

Henceforth, when building projects for cooperation between China and the US, it is of crucial importance that these projects are designed in a way to benefit both sides and bypass any points which may create conflicts. Studying the case of Apple and Sun Power I have pointed out that developing the projects with locally manufactured equipment and excluding trade of solar elements in the process may be a key element for creating collaboration in the solar sector without letting it give rise to disputes.

In the last few years both China and the US are investing heavily in solar energy and have taken it as a priority factor in their future development. This is because both countries have to face a number of issues connected to the environment and the energy security. For this reason, joining efforts and working together to resolve these issues can certainly have a positive impact on their state-to-state relations.

Moreover, this kind of collaboration brings benefits not only to the actors who directly participate in it but also to local people by providing them with clean electricity. From a global perspective, solar projects affect in a positive way the environment by saving millions of metric tons of $\mathrm{CO}_{2}$ from being released in the atmosphere. In this way, the solar technology can help tackle climate changeone issue which is increasingly becoming a top priority on the agenda of many governments. And here we can see one very important aspect of the collaboration in the solar sector-it unites countries under ideas which all people relate to: clean environment, energy security, peaceful relations and a better future for those who will come after us.

Therefore, it is imperative that policymakers use solar energy to its full potential to enhance international cooperation and bring companies, governments, non-governmental organizations and individuals to work together for promoting renewable energy and combating climate change.

\section{Conclusions}

The solar energy sector offers a vast range of possibilities for cooperation on many levels. Nevertheless, it can also give rise to confrontation as we see in the case of the solar trade disputes between the US and China.

Since solar energy has proven to have a positive impact both in economic and environmental aspect, it is important to minimize any potential conflicts which it can bring, while at the same time keep promoting the solar energy proliferation on a global scale.

In this regard, the cooperation between major powers like China and the US has an imperative role in the shift towards a sustainable low-carbon economy and the deepening of the reliance on renewable energy which comes with it. Furthermore, the Sino-American cooperation in all sectors is crucial for the promotion of peaceful relations on the international arena. Therefore, bringing together the two most important players on the international arena and creating 
conditions for them to work together for the benefit of all, is important and at the same time-a challenging task.

Nevertheless, if we analyze the joint projects between Apple and Sun Power, we can see that the two companies have achieved namely this: collaboration between an American and a Chinese-operating company, promotion of the solar industry, creation of environmentally-friendly business, lowering of $\mathrm{CO}_{2}$ emissions, benefit for local people with minimum impact on the environment and all this without giving rise to any trade frictions or any kinds of disputes whatsoever. For this reason, I argue that solar energy can be used as a basis to develop the economy of any country in an environmentally friendly way and additionally, promote peace on the international arena.

\section{References}

[1] (2017) America's Pledge, Press Release. https://www.americaspledgeonclimate.com/

[2] Abraham, J. (2017) Despite Trump, American Companies Are Still Investing in Renewable Energy. The Guardian.

https://www.theguardian.com/environment/climate-consensus-97-per-cent/2017/o ct/11/despite-trump-american-companies-are-still-investing-in-renewable-energy

[3] Zhou, C.H. (2015) Economic Analysis of the Trade Frictions between China and the US in the Area of New Energy Industry. Renmin University of China, Beijing. http://www.ckni.net

[4] Trabish, H.K. (2013) How to Settle the US-China Solar War. Greentech Media. https://www.greentechmedia.com/articles/read/how-to-get-the-u-s-china-solar-war -settled\#gs.x3Zizu8

[5] Steeves, B.B. and Ouriques, H.R. (2016) Energy Security: China and the United States and the Divergence in Renewable Energy. Contexto Internacional, 38, 5-7. https://doi.org/10.1590/S0102-8529.2016380200006

[6] Steeves, B.B. and Ouriques, H.R. Energy Security: China and the United States and the Divergence in Renewable Energy. 8.

[7] Steeves, B.B. and Ouriques, H.R. (2016) Energy Security: China and the United States and the Divergence in Renewable Energy. 38, 10-11.

[8] Global Distribution of Energy Resources. http://www.bbc.co.uk/education/guides/z3pppv4/revision

[9] Steeves, B.B. and Ouriques, H.R. Energy Security: China and the United States and the Divergence in Renewable Energy. 7. http://www.scielo.br/pdf/cint/v38n2/0102-8529-cint-38-02-00643.pdf

[10] Kassiola, J.J. (2010) China's Environmental Crisis: Domestic and Global Political Impacts and Responses. https://books.google.com.hk/books?id=caDGAAAAQBAJ\&redir_esc=y

[11] Introductory Course in Renewable Energy. www.solarenergyinternational.com

[12] Before the Flood, National Geographic Channel, 2016. http://channel.nationalgeographic.com/before-the-flood/

[13] Sachs, J.D. (2015) The Age of Sustainable Development. Columbia University Press. https://doi.org/10.7312/sach17314

[14] Steeves, B.B. and Ouriques, H.R. (2016) Energy Security: China and the United States and the Divergence in Renewable Energy. 38, 6. 
[15] Group of Authors (2013) China's Coal Reserves Might Only Last for 33 More Years. China Electricity News Network. http://www.fdi.gov.cn/1800000121_21_53311_0_7.html

[16] Steeves, B.B. and Ouriques, H.R. Energy Security: China and the United States and the Divergence in Renewable Energy. 8.

[17] Group of Authors (2017) Introduction to Renewable Energy. Online Course at Solar Energy International. www.solarenergyinternational.com

[18] He, F. (2016) China 2016, in Pursue of New Driving Force. Chinese Literature and History Press.

[19] Allen, D. (2016) China's Solar Surge Presents Future Opportunity. East West Bank. https://www.eastwestbank.com/ReachFurther/News/Article/China-Solar-Surge-Pre sents-Future-Opportunity

[20] The White House, Office of the Press Secretary, US-China Joint Announcement on Climate Change, Point 5, Beijing, China, 12 November 2014, Points 1, 2 and 8. https://obamawhitehouse.archives.gov/the-press-office/2014/11/11/us-china-joint-a nnouncement-climate-change

[21] The US-China Renewable Energy Partnership (USCREP). http://www.us-china-cerc.org/about.html

[22] McDonnell, T. and West, J. (2014) The US and China Just Announced a Huge Deal on Climate-And It's a Game Changer.

http://www.motherjones.com/environment/2014/11/obama-just-announced-histori c-climate-deal-china

[23] Snieckus. D. (2016) US and Chinese Researchers Boost Perovskite Solar Cell Performance. Recharge News.

http://www.rechargenews.com/solar/1183068/us-and-chinese-researchers-boost-per ovskite-solar-cell-performance

[24] Ma, J. (2015) Research on the Fiscal and Taxation Policies for Financing and Expanding China's Clean Energy Resources. http://image.cnki.net/detail/1015518061.nh0005.html

[25] Mason, J. (2017) China to Plow $\$ 361$ Billion into Renewable Fuel by 2020. Global Energy News.

http://www.reuters.com/article/us-china-energy-renewables-idUSKBN14P06P

[26] Kaartemo, V. (2017) Creation and Shaping of the Global Solar Photovoltaic (PV) Market. Turku School of Economics, University of Turku, Finland.

[27] Vans, A. (2015) Elon Musk: Tesla, SpaceX, and the Quest for a Fantastic Future. Ecco Publishing Press.

[28] Green, M.A. (2016) Revisiting the History Books. PV Magazine, Point 1 and 2. https://www.pv-magazine.com/magazine-archive/revisiting-the-history-books_1000 24938/\#axzz4HkmP7QH3

[29] (2016) Figure 2, Based on John A. Mathews Manufacturing of Solar PV Panels, by Country, 1995-2015 “China's Continuing Renewable Energy Revolution-Latest Trends in Electric Power Generation. The Asia-Pacific Journal. http://apjjf.org/2016/17/Mathews.html

[30] Figure 3. https://commons.wikimedia.org/wiki/File:China_Photovoltaics_Installed_Capacity. svg

[31] (2014) The WTO Helps the US Impose Anti-Dumping and Anti-Subsidy Duties for Solar PV Imports. Semiconductor Equipment and Materials International (SEMI). 
http://www.semi.org.cn/pv/news_show.aspx?ID=14684\&classid=12

[32] Stein, J. (2017) The Case for US Solar Manufacturing. PV Magazine. https://pv-magazine-usa.com/2017/08/31/the-case-for-u-s-solar-manufacturing/

[33] The White House, Office of the Press Secretary, US-China Joint Announcement on Climate Change, Point 5, Beijing, China, 12 November 2014, Point 5. https://obamawhitehouse.archives.gov/the-press-office/2014/11/11/us-china-joint-a nnouncement-climate-change

[34] Al Gore, Interview, "Paris Agreement Is a Strong Signal That "We Will Solve Climate crisis", Al Gore Says Leading Environmental activist Says Cheaper Renewable Energy Provides an Opportunity to Create a Sustainable World Economy-But We Must Do More.

http://www.theguardian.com/environment/2016/apr/30/paris-agreement-is-a-stron g-signal-that-we-will-solve-climate-crisis-al-gore-says

[35] http://newsroom.sunpower.com/press-releases?item $=122885$

[36] Cardwell, D. (2016) Apple Becomes a Green Energy Supplier, With Itself as Customer. The New York Times.

https://www.nytimes.com/2016/08/24/business/energy-environment/as-energy-userises-corporations-turn-to-their-own-green-utility-sources.html

[37] Martin, R. (2016) Foxconn Wants to Become a Global Force in Clean Energy. MIT Technology Review.

https://www.technologyreview.com/s/601208/foxconn-wants-to-become-a-global-f orce-in-clean-energy/

[38] Zhou, Y.M. (2017) When Some US Firms Move Production Overseas, They Also Offshore Their Pollution. The Conversation.

http://theconversation.com/when-some-us-firms-move-production-overseas-they-a lso-offshore-their-pollution-75371

[39] Dent, M. (2015) 5 American Companies Going Strong in China. The Fiscal Times. http://www.thefiscaltimes.com/2015/11/06/5-American-Companies-Going-StrongChina

[40] Costello, S. (2017) Where Is the iPhone Made? Life Wire, The iPhone's Assemblers. https://www.lifewire.com/where-is-the-iphone-made-1999503

[41] Pressman, A. (2016) Solar Power From Apple Could Light Up Your Home. Fortune. http://fortune.com/2016/08/04/apple-approval-solar-electricity/

[42] Wang, U. (2015) Apple Goes to China to Build Solar Projects WithSunPower. Forbes.

https://www.forbes.com/sites/uciliawang/2015/04/16/apple-goes-to-china-to-buildsolar-projects-with-sunpower/

[43] Montejo, E. (2015) Apple's China Operations Now Running on 100\% Green Power. Techlicious.

https://www.techlicious.com/blog/apples-china-operations-now-running-on-100-p ercent-green-power/

[44] Apple Newsroom (2016).

http://www.apple.com/newsroom/2016/08/apple-announces-environmental-progre ss-in-china.html

[45] Sun Power Press Release, Sun Power Newsroom (2015).

http://newsroom.sunpower.com/2015-04-16-SunPowers-China-Joint-Venture-Part ners-with-Apple-to-Provide-Solar-Power-to-the-Environmentally-Preserved-ABA$\underline{\text { Region }}$ 
[46] "Computerworld; Apple Unveils 18-Megawatt Solar Farm to Power Cloud Data Center”, Nevada Governor's Office of Economic Development (2012).

http://www.diversifynevada.com/news/apple-data-center-boosts-nevadas-it-profilenational-

ly/computerworld-apple-unveils-18-megawatt-solar-farm-to-power-cloud-data-cen $\underline{\mathrm{t}}$

[47] Mearian, L. (2016) Apple Commits to Run off 100\% Renewable Energy. Many of Apple's Chinese Parts Suppliers Have Also Committed to Use 100\% Renewable Energy in the Production of Apple Products. Computerworld.

http://www.computerworld.com/article/3122461/sustainable-it/apple-commits-to-r un-off-100-renewable-energy.html

[48] (2015) China 2050 High Renewable Energy Penetration Scenario and Roadmap Study.

http://www.efchina.org/Attachments/Report/report-20150420/China-2050-High-Ren ewable-Energy-Penetration-Scenario-and-Roadmap-Study-Executive-Summary.pdf

[49] Fehrenbacher, K. (2016) How Apple's Solar Strategy Evolved. http://fortune.com/2016/03/23/apple-clean-energy-evolution/

[50] Apple, Environmental Responsibility Report 2017, 11. https://images.apple.com/au/environment/pdf/Apple_Environmental_Responsibilit y_Report_2017.pdf

[51] Apple, Environmental Responsibility Report 2017, Figure 4. https://images.apple.com/au/environment/pdf/Apple_Environmental_Responsibilit y_Report_2017.pdf

[52] Elmer-DeWitt, P. (2015) How Big Is Apple’s Green Initiative in China? Fortune. http://fortune.com/2015/10/22/apple-china-solar/

[53] The Power of Renewables: Opportunities and Challenges for China and the United States (2010) Chapter: 7 US-Chinese Cooperation, Overview of US-Chinese Cooperation, 176. https://www.nap.edu/read/12987/chapter/9\#176

[54] Shaw, V. (2015) Apple, SunPower Join Forces to Invest in $170 \mathrm{MW}$ of Solar in Inner Mongolia. PV Magazine.

https://www.pv-magazine.com/2015/11/24/apple-sunpower-join-forces-to-invest-in -170-mw-of-solar-in-inner-mongolia_100022121/

[55] Mearian, L. (2015) Apple's \$850M Solar Plant Rockets It to First Place among US Corporations. Computer World.

https://www.computerworld.com/article/2882762/apples-850m-solar-plant-rocketsit-to-first-place-among-us-corporations.html

[56] Consultation with Risen Energy Co., Ltd. Project Development Representative.

[57] International Center for Trade and Sustainable Development.

http://www.ictsd.org/bridges-news/bridges/news/china-launches-solar-case-against -eu-at-wto

[58] (2015) US-China Joint Presidential Statement on Climate Change, The White House Press Release.

https://www.whitehouse.gov/the-press-office/2015/09/25/us-china-joint-presidentia 1-statement-climate-change

[59] Tverberg, G. (2012) Is Constant Economic Growth Possible? Oilprice. http://oilprice.com/Finance/the-Economy/Is-Constant-Economic-Growth-Possible. $\underline{\mathrm{html}}$

[60] Eisenstein, C. (2012) Sacred Economics. Money, Gift \& Society in the Age of Transition. Evolver Editions. 
[61] 2014 Progress Report. Apple (2014). https://www.apple.com/environment/reports/docs/apple_environmental_responsibi lity_report_0714.pdf

[62] Online Solar Training and Renewable Energy Courses-Solar Energy International (SEI)-Renewable Energy Characteristics. https://solarenergytraining.org/login/index.php\#section-4

[63] Zhang, X.L. (2016) Director of the Chinese Institute for Energy, Environment and Economy in Beijing, Professor at Qinghua University, The Breakthrough in Renewable Energy. Vpro Documentary. https://www.youtube.com/watch?v=mmyrbKBZ6SU

[64] Apple, Environmental Responsibility Report (2017). https://images.apple.com/lae/environment/pdf/Apple_Environmental_Responsibilit y_Report_2017.pdf

[65] Sverdlik, Y. (2013) Apple Reaches 100\% Renewable Energy across All Data Centers. http://www.datacenterdynamics.com/content-tracks/design-build/apple-reaches-10 0-renewable-energy-across-all-data-centers/74708.fullarticle

[66] (2016) Press Release: “Apple Announces Environmental Progress in China \& Applauds Supplier Commitment to Clean Energy. Apple Newsroom.

http://www.apple.com/newsroom/2016/08/apple-announces-environmental-progre ss-in-china.html

[67] Costello, S. (2017) Where Is the iPhone Made? Life Wire. The iPhone's Component Manufacturers. https://www.lifewire.com/where-is-the-iphone-made-1999503

[68] Online Solar Training and Renewable Energy Courses-Solar Energy International (SEI) - Solar PV Panel Production https://solarenergytraining.org

[69] Renewable Energy 100, Global Movement (2017). http://there100.org/re100

[70] Apple News Room, Press Release, 2015. https://www.apple.com/uk/newsroom/2015/10/22Apple-Launches-New-Clean-Ener gy-Programs-in-China-To-Promote-Low-Carbon-Manufacturing-and-Green-Grow th/

[71] Financial Times, Section "Solar Wars" (2017). https://www.ft.com/topics/themes/Solar_Wars 